\title{
O Mito Trágico de Salvador Dalí
}

\author{
Nuno Pinto Ferreira \\ Associação Portuguesa de Psicanálise e Psicoterapia Psicanalítica - pintoferreira.psi@gmail.com
}

\section{Carlos Farate}

Instituto Superior Miguel Torga; Sociedade Portuguesa de Psicanálise; Centro de Estudos da População,

Economia e Sociedade - ccfarate@gmail.com

\section{Henrique Testa Vicente}

Instituto Superior Miguel Torga; Centro de Estudos da População, Economia e Sociedade -

henrique.t.vicente@gmail.com

\section{Sumário}

Este artigo propõe uma leitura crítica da autoanálise esboçada por Salvador Dalí na obra "O mito trágico do Angelus de Millet" à luz da interpretação de uma dinâmica familiar sob o primado da fantasia do infans de substituição. Sugere-se que esta narrativa, elaborada segundo o método paranoico-crítico, sobrepõe mito pessoal e ficção, alegoria omnipotente e reinterpretação delirante da saga familiar trágica, de uma díade mãe-filho permeada pela evocação histórica do "resgate" fantasmático de um irmão morto nove meses antes do seu nascimento. Foram triangulados excertos do texto sobre o Angelus, dados biográficos e aportes de Bion sobre a importância dos mitos privados na construção da identidade. Conclui-se que Dalí ensaiou a aproximação a outra dimensão do imago materno, que os outros escritos e atos autobiográficos aparentam contradizer, mais precisamente a Mãe Antígona que “enterra" o corpo do filho in statu nascendi sob o olhar cúmplice e impotente do pai. Realça-se a importância de Gala como figura da Anunciação de destino trágico-grandioso, segundo a mística bíblica do "Filho Unigénito do Pai", solução romanceada, de cariz surrealista e delirante, para aquela que terá sido a problemática central da sua existência, a condição de criança de substituição de um Outro temido e desconhecido.

Palavras-Chave: Salvador Dalí, mito privado, Angelus de Millet, criança de substituição, psicanálise.

\section{The Tragic Myth of Salvador Dalí}

\begin{abstract}
This paper proposes a critical reading of the self-analysis outlined by Salvador Dalí in the essay "The tragic myth of Millet's Angelus", in

the light of the interpretation of a family dynamic under the primacy of the replacement infans fantasy. It is suggested that this narra-
\end{abstract}


tive, elaborated accordingly to the paranoiaccritical method, superimposes personal myth and fiction, omnipotent allegory and delirious reinterpretation of the tragic familial saga of a mother-child dyad permeated by the historical evocation of the phantasmatic "recovery" of a brother that died nine months before his birth. The authors triangulated selections from the dalinian text on the Angelus, biographical data and Bion's contributions regarding the importance of private myths in the construction of identity. It is concluded that Dalí rehearses an approximation to another dimension of the maternal imago that other written autobiographical elements seem to contradict. More precisely, the Mother Antigone that "buries" the body of her in statu nascendi son under the father's impotent and accomplice gaze. Also highlighted is the importance of Gala as a figure of the Annunciation of a tragic-grandiose destiny, according to the biblical mysticism of the "Only begotten Son of the Father", a romanced solution, of surreal and delusional nature, for the probable central issue of his existence, the condition of replacement child of a dreaded and unknown Other.

Keywords: Salvador Dalí, private myth, Millet's Angelus, replacement child, psychoanalysis.

\section{INTRODUÇÃOO}

O Angelus (1857-1859) é uma pintura de estilo realista produzida pelo pintor francês Jean-François Millet, cuja intenção original seria, segundo Joana e Carlos Amaral Dias (2015), representar uma catástrofe agrária que teria destruído as colheitas de batatas. Assim, aos pés da mulher nele figurada vemos uma cesta com batatas podres e os dois camponeses retratados apresentam um ar de lamento diante da destruição (ver Figura 1).

A composição deste quadro é de extrema simplicidade. Do ponto de vista iconográfico, consiste num campo com uma linha de horizonte bem marcada onde, numa posição um pouco mais elevada e ao centro da cena pictórica, aparecem duas personagens, um homem e uma mulher, aparentando estarem ambos concentrados em si mesmos, ensimesmados e absortos, rezando o Angelus (oração recordatória do momento da Anunciação da conceção de Jesus Cristo, da Encarnação da divindade, e cujo nome deriva do início da frase em latim "Angelus Domini nuntiavit Mariøe). Aos seus pés, entre os dois, encontra-se um cesto. Por detrás da mulher vê-se um carro-de-mão e, junto à figura masculina, uma forquilha cravada no chão. A gama 
cromática reforça esta mesma simplicidade, com tonalidades que se situam entre os ocre-amarelados e os azuis-grizáceos, reservados à zona do céu. Apesar da verticalidade das personagens, sobressai uma sensação de total estaticismo, proporcionada pela horizontalidade da clara e definida linha do horizonte, cuja atmosfera carregada de mistério é dotada de um sentimento trágico que facilmente se poderá relacionar com a morte, isto para além do par de figuras aparentarem uma angústia profunda (Cirlot, 2003).

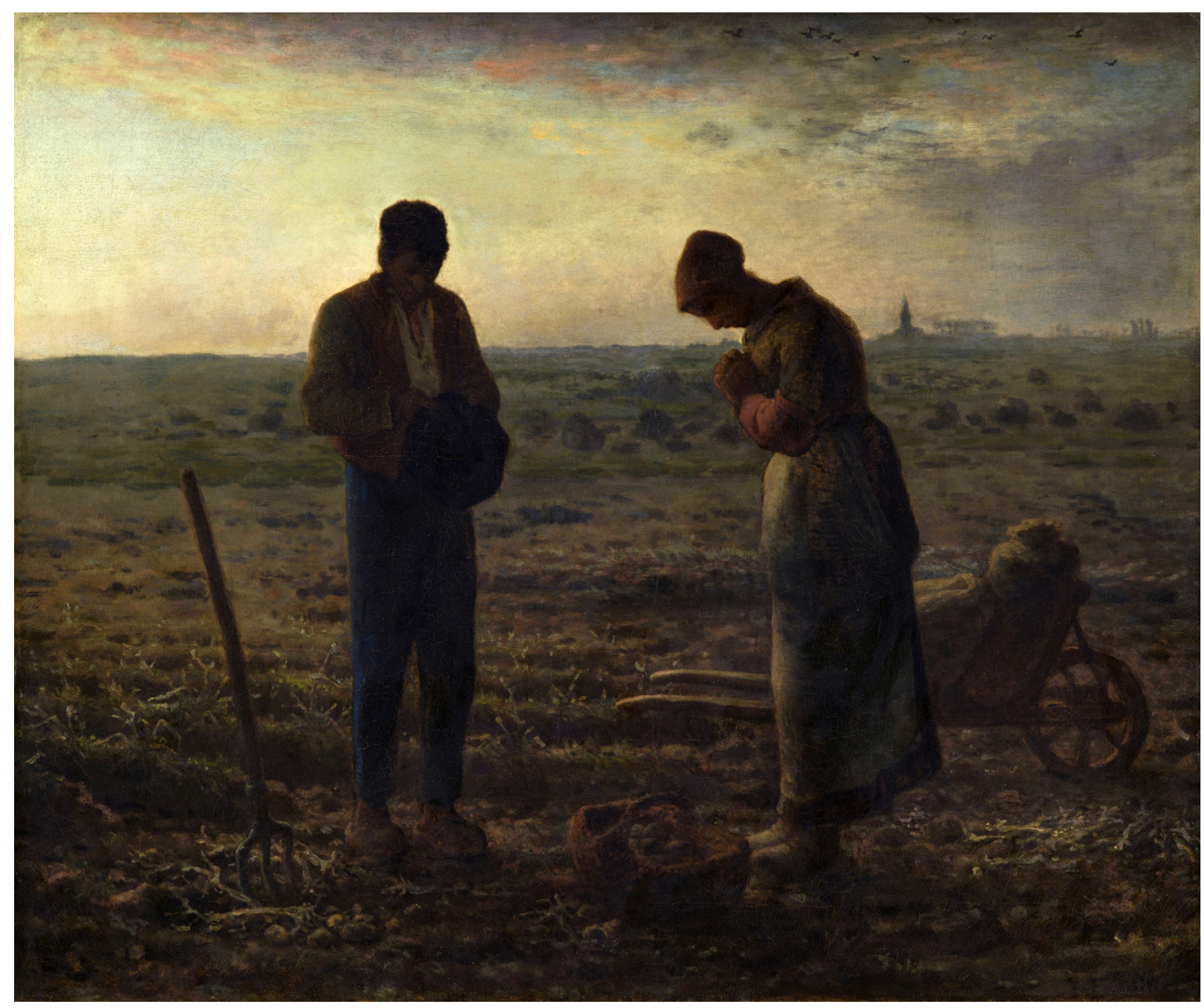

Figura 1. Angelus, por J.-F. Millet, ca. 1857-1859 (Musée d’Orsay, Paris).

Entre 1932 e 1936, este quadro produz um efeito avassalador num dos vultos maiores da pintura contemporânea, Salvador Dalí (1904-1989), tornando-se subitamente aos seus olhos "a obra pictórica mais perturbadora, mais enigmática, mais 
densa, mais rica em pensamentos inconscientes que jamais existiria" (Dalí, 1998, p. 54), resultando este efeito numa variada produção criativa em diversas áreas artísticas (e.g. Meditação sobre a Harpa, 1932-34; O Angelus Arquitectónico de Millet, 1933; Busto de Mulher Retrospectivo, 1933; Atavismo do Crepúsculo (Fenómeno Obsessivo), 1933-34; Reminiscência Arqueológica de «O Angelus» de Millet, 1935), entre as quais se conta o ensaio surrealista "O mito trágico do Angelus de Millet" (Dalí, 1978, 1998).

Dalí não seria o único em quem os efeitos inconscientes deste quadro se fizeram sentir. O próprio assim o reconhece, outorgando-lhe a categoria de fenómeno social ao salientar "o poder obsessivo que a imagem aparentemente "insignificante" do Angelus de Millet exerceu no mundo inteiro e sobre a imaginação de multidões. Com efeito, este quadro bate de longe, seguramente, todos os recordes de reprodução" (Dalí, 1998, p. 59).

Reconhecendo um irresistível e irreprimível poder atrativo neste quadro, no plano coletivo, mas sobretudo nele próprio, questiona: "então como explicar (...) esta inegável violência exercida sobre a imaginação (...) como conciliar esta força, mesmo esta fúria das representações com o aspecto miserável, tranquilo, insípido, imbecil, insignificante, estereotipado, convencional em tristíssimo grau do Angelus de Millet?" (Dalí, 1998, p. 60).

A resposta surge elaborada no ensaio supracitado, através de uma filosofia própria, a "teoria paranóico-crítica" ou "método do conhecimento irracional baseado na associação interpretativa-crítica dos fenómenos delirantes" (Ades, 1982; Cirlot, 2003; Dalí, 1998), cujas bases teóricas se fundam na tese de doutoramento de Lacan, intitulada "Da psicose paranóica nas suas relações com a personalidade" (1932/1980), e que permitem a Dalí (1998) enunciar:

Paranóia: delírio de associação interpretativa comportando uma estrutura sistemática - Actividade paranóico-crítica: método espontâneo de conhecimento irracional baseado na associação interpretativa-crítica dos fenómenos delirantes. A presença de elementos activos e sistematizados próprios da paranóia garante $\mathrm{o}$ carácter evolutivo e produtivo da actividade paranóico-crítica. (...) A actividade paranóico-crítica já não considera os fenómenos e imagens surrealistas isoladamente, mas pelo contrário, num conjunto coerente de relações sistemáticas e significativas. (pp. 16-17) 
Segundo o pintor, "a actividade paranóico-crítica descobre por este método «significações» novas e objectivas do irracional, faz passar tangivelmente o próprio mundo do delírio para o plano da realidade" (Dalí, 1998, p. 18). Para o historiador e crítico de arte José Pierre, este método poderá ser das contribuições mais significativas do artista para o surrealismo, suplantando mesmo o automatismo, que era a pedra angular daquele movimento artístico (Cirlot, 2003).

Para sistematizar o estudo do Angelus segundo a sua metodologia, Dalí estabelece três níveis no seu ensaio (Cirlot, 2003): descritivo, interpretativo e de síntese e interpretação profunda da obra. O primeiro trataria dos fenómenos delirantes, inicial e secundários, descrevendo fantasias de caráter obsessivo do autor ou as "visões" do Angelus. No nível seguinte da obra, Dalí procura sustentar que existe algo na pintura que não se revela pela simples contemplação, mas apenas através de uma análise aprofundada, através da associação dos fenómenos descritos no capítulo precedente. No terceiro e último nível, Dalí expõe metodicamente o mito ancestral que crê estar contido no Angelus, o mito do infanticídio, ou, nas palavras do autor, "a variante maternal do mito imenso e atroz de Saturno, de Abraão, do Pai Eterno com Jesus e mesmo de Guilherme Tell, devorando os seus próprios filhos" (Dalí, 1998, p. 107). Mais adiante, no presente trabalho, os diversos elementos deste ensaio serão abordados em maior pormenor.

Um dado importante na compreensão da obra criativa de Dalí no geral, e de " $O$ mito trágico do Angelus de Millet” em particular, será a sua obsessão pela psicanálise. Freudiano acérrimo desde os tempos de estudante em Madrid (Rudín, 2004), a influência do pensamento do psicanalista austríaco aparece condensada numa breve passagem do seu "Diário de um Génio" em que o cérebro de Freud é descrito como um dos mais saborosos e importantes da nossa época (Dalí, 1964/2008). Com efeito, a leitura de "A Interpretação dos Sonhos" produz um grande impacto no pintor catalão, que declara ter sido "uma descoberta capital", passando a realizar uma "auto-interpretação", não apenas dos seus sonhos, mas de tudo o que lhe acontecia (Ades, 1982). Consequentemente, os postulados freudianos começam a ser utilizados por Dalí para explicar a paranoia e os comportamentos excessivos, como ferramentas auxiliares em prol do seu autoconhecimento. Repercutem-se igualmente na produção artística, onde a obsessão pela conquista do irracional, associada à sua inquietude, se traduziu na elaboração de um simbolismo pictórico e linguístico totalmente idiossincrático (Ades, 1982; Martínez-Herrera, Alcántara, \& García-Fernández, 2003; McNeese, 2006). 
O encontro entre Dalí e Freud acaba por acontecer, após várias tentativas do pintor, a 19 de julho de 1938, em Londres, por mediação de Stefan Zweig, um ano antes da morte do fundador da psicanálise (Ades, 1982; McNeese 2006; Rudín, 2004). A propósito da conversação que os dois mantiveram, Dalí assinalou que Freud terá falado várias vezes em sublimação (Rudín, 2004) e que terá comentado:

It is not the unconscious I seek in your pictures, but the conscious. While in the pictures of the masters - Leonardo or Ingres - that which interests me, that which seems mysterious and troubling to me, is precisely the search for unconscious ideas, of an enigmatic order, hidden in the picture, your mystery is manifested outright. The picture is but a mechanism to reveal it. (Ades, 1982, p. 74)

É precisamente na senda da inspiração diacrítica contida nestas palavras de Freud que o presente estudo contorna a obra pictórica do catalão, para se centrar num texto muito particular do corpus daliniano - "O mito trágico do Angelus de Millet" -, um ensaio onde humor, entomologia e psicanálise se reúnem na construção de uma obra de cariz "científico", que visa sustentar a proficuidade para a investigação do método paranoico-crítico por ele divisado. A hipótese de trabalho seria que esta obra, onde é abordado o grande tema mítico da morte do filho, embora não seja marcadamente autobiográfica (e talvez precisamente por isso), no sentido em que se poderiam considerar outros escritos do pintor, como o "Diario de un Genio" (Dalí, 1964/2008) ou “The Secret Life of Salvador Dali” (Dalí, 1942/1986), pela descrição dos seus íntimos "fenómenos delirantes" e dos padrões associativos a eles ancorados, pode revelar algo mais "verdadeiro" acerca da sua personalidade, das suas fantasias inconscientes, do que o discurso hiperbólico das suas descrições vivenciais nos textos assumidamente biográficos. Relembre-se, a título de paralelismo, que alguns autores sustentam que em "A Interpretação dos Sonhos", ao relatar 47 sonhos que lhe pertenciam, Freud terá porventura revelado mais detalhes da sua vida íntima do que o fez na autobiografia (Roudinesco \& Plon, 1998).

Segundo Hartman (2008), a obsessão de Dalí pela elaboração de um mito próprio evidencia conflitos psicológicos que, em primeira instância, remetem para a história do seu desenvolvimento. Com efeito, em adulto intitula-se "grande paranóico" (Rudín, 2004), título que indicia uma marca transgeracional que remonta ao seu avô paterno, Gal Josep Salvador Dalí. Pese embora a sua omissão nos registos autobiográficos, este último teria sido diagnosticado como sofrendo de delírios persecutórios 
que, associados à perda de avultadas quantias de dinheiro nas casas de câmbio em Barcelona, culminam no suicídio. Para além do avô, também o seu tio Rafael tentaria suicidar-se, todavia sem sucesso (Hartman, 2008).

À transgeracionalidade acrescem eventos relacionados com a infância que se repercutiram indelevelmente no seu caráter (Martinez-Herrera et al., 2003). Um desses eventos relaciona-se com a condição de "criança neo-nascida", segundo Joana e Carlos Amaral Dias (2015), ou "criança de substituição" ("replacement-child"), nas palavras de Hartman (2008). Apesar da diferença terminológica, estes autores reportam-se ao mesmo fenómeno: "the designation of replacement child refers to one whose parents made a conscious decision to conceive a child in order to replace a child who died a short time earlier" (Hartman, 2008, p. 536), desejo esse que poderá ter estado relacionado com o nascimento de Dalí, visto que ocorreu exatamente nove meses e onze dias após a morte de um irmão mais novo, que o precederia na fratria, ao que acresce a partilha do mesmo nome próprio, Salvador (Amaral Dias \& Amaral Dias, 2015; Hartman, 2008).

Existem poucos dados quer sobre a prevalência, quer sobre os efeitos deste fenómeno no desenvolvimento da personalidade nos inícios do século XX, embora as elevadas taxas de mortalidade infantil apontem para a possibilidade deste ocorrer amiúde. A "criança de substituição" apenas granjeou o interesse dos investigadores a partir da década de 1960 (Hartman, 2008), salientando-se o estudo pioneiro de Cain e Cain (1964) baseado em seis casos clínicos. Estes autores identificaram um luto pseudo-resolvido nos pais e a omnipresença da imagem idealizada da criança falecida:

The new child, the substitute, then, was born into a world of mourning, of apathetic, withdrawn parents, a world focused on the past and literally worshiping the image of the dead (...) These parents grossly imposed the identity of the dead child upon his substitute, and unconsciously identified the two. Frequent slips were made, calling the new child by the dead child's name (...) The two children's looks, posture, facial expressions, ways of walking and talking were constantly compared. The parents' expectations, hopes, and even demands upon the child for various kinds of excellence were all obviously modeled upon the achievements of the dead child - or, more accurately, upon the hyperidealized and grossly unrealistic image of the dead child. (Cain \& Cain, 1964, pp. 445-447) 
Outro dos elementos identificados por Cain e Cain (1964) foram as preocupações fóbicas dos pais acerca de doenças e acidentes, que resultariam numa superproteção e imposição de restrições severas aos filhos substitutos. Estes, por seu turno, manifestavam múltiplas fobias e preocupações mórbidas acerca da morte, tendendo a identificar-se com o irmão falecido e, como tal, a "amputar" a sua individualidade:

They found they could barely breathe as individuals with their own characteristics and identity. Their parents compelled them to be like their dead siblings, to be identical with them, yet made it clear that they would never be accepted as "the same," and could never really be as good. (Cain \& Cain 1964, p. 451)

Frequentemente, os pais atribuem à criança viva o nome da criança morta. Segundo Joana e Carlos Amaral Dias (2015), na criança neo-nascida, o nome coloca-a, pela via do homónimo morto, como personagem que se confunde no face-a-face fantasmático com uma imagem especular, isto é, igual a si-mesmo, promovendo facilmente uma fragmentação aniquiladora. Terá sido assim com Dalí, mas também com Vincent Van Gogh. As suas histórias de desenvolvimento apresentam pontos de contacto que convirá salientar. Van Gogh nasce um ano depois da morte do irmão e também ele herda o nome próprio do falecido (Hartman, 2008).

A questão que aqui se coloca é de ordem identitária, e a história de vida destes sujeitos tende a evidenciar precisamente as dificuldades na elaboração de uma identidade viável separada daquela do irmão morto. A dinâmica familiar em que estão inseridos poderá estar implicada nestas dificuldades, no sentido, consciente ou pré-consciente, de que a criança viva ocupe o lugar de Outro. Ela é o representante do desejo materno de negar a morte de um outro filho (Amaral Dias \& Amaral Dias, 2015). Com efeito, no fenómeno das crianças neo-nascidas, os progenitores em geral, e a mãe em particular, detêm um papel primordial. Os mesmos autores referem que a mãe, vítima de um luto não realizado e para sobreviver narcisicamente, gera uma nova vida para substituir o outro, o filho falecido/enterrado, o que pode dar lugar a uma "maternagem" (Winnicott, 1975) impregnada pelas agonias, memórias e acontecimentos conectados à criança morta, e tendente a comprometer o desenvolvimento de uma função "continente" na criança em processo de substituição, pela falha da capacidade de rêverie materna. Hartman (2008) assinala ainda que as crianças de substituição poderão experienciar sentimentos de 
responsabilização pela aflição dos pais e apresentar fantasias de imputação de culpa pela morte do irmão.

Os registos autobiográficos de Dalí evidenciam que este se sentiu e identificou como criança substituta ao longo da sua vida, providenciando amplo material que atesta o impacto desta condição na sua existência (Dalí, 1942/1986, 1973/1975). Nos escritos que se reportam ao irmão morto, é possível identificar omissões e erros factuais (por exemplo, refere que o irmão morreu aos sete anos de idade, quando na realidade faleceu aos 21 meses), um misto de realidade e ficção (a título exemplificativo, atribuía ao irmão características que uma criança de tão tenra idade não poderia demonstrar) que, segundo Hartman (2008), são reveladores de conflitos identitários e da construção de um mito próprio, visando uma nova identidade e uma nova personalidade.

Do ponto de vista psicanalítico, o mito tem um papel preponderante, primeiramente com Freud, que referia em "Psicopatologia da Vida Quotidiana" (1901/2003, p. 288) que "a concepção mitológica do mundo, que se repercute até nas religiões mais modernas, não é mais que uma psicologia projectada no mundo exterior" cuja análise desvelaria fatores e factos psíquicos do inconsciente, sendo que outros distintos psicanalistas seguem a mesma senda (e.g. Rank, 1959; Lacan, 1987), nomeadamente Wilfred Bion, que sustenta com firmeza a importância do mito na fantasia do sujeito.

Outro dos postulados de Freud consiste na aproximação da narrativa mítica ao sonho, defendendo que diferentes episódios míticos/sonhos são diferentes versões distorcidas de um mesmo conteúdo à procura de sentido, a passagem do não sabido ao visto (tornado consciente). Mito e Mitologia, no pensamento do pai fundador da psicanálise, contêm as ancestrais fantasias do início dos tempos: "a figura mítica condensa as realidades culturais e psicológicas mais profundas da Humanidade. $\mathrm{O}$ enigma da esfinge ganha em Freud o sentido do enigma da condição humana" (Fleming, 2003, p. 151).

Por sua vez, Bion toma como ponto de partida as hipóteses freudianas e desenvolve a temática do mito, nomeadamente o conceito que denominou de "Mito Privado", que poderá ser sistematizado em duas grandes áreas: "o Mito enquanto modelo para o crescimento mental" e "o Mito enquanto conceito integrado na teoria de pensamento" (Fleming, 2003, p. 152).

Relativamente à primeira conceptualização, Bion contraria as perspetivas que dissociam o Mito do Logos, e associa-o ao vínculo do conhecimento $(\mathrm{K})$ da sua teoria do pensamento. Desta forma, Fleming (2003) sublinha a convergência entre os dois 
autores acima referenciados, no sentido em que, para ambos, o mito representa fonte de conhecimento cujo código simbólico, uma vez descodificado, permitiria o acesso ao saber. Consequentemente, pode ser entendido como modelo para o crescimento mental, operado pela tolerância à dor mental, porque "só a tolerância à dor mental e o não temor pelo desconhecido podem conduzir o homem à descoberta da sua verdade, à busca do conhecimento de si próprio" (Fleming 2003, p. 152).

Na segunda conceptualização de Bion, o mito insere-se na categoria $\mathrm{C}$ da sua tabela, onde agrupa três ordens de fenómenos mentais: sonhos, pensamentos oníricos e mitos. O sonho é perspetivado como uma combinação em forma narrativa de pensamentos oníricos que, por sua vez, derivam de combinações de elementos alfa. Para Bion, pensamentos oníricos, sonhos e mitos seriam construções de um mesmo tipo; todavia, diferenciam-se entre si pela qualidade e natureza do fenómeno: "Pensamentos Oníricos e Sonhos são fenómenos inconscientes", enquanto "relatos de sonhos e mitos são pensamentos conscientes". Nesta linha de pensamento, pode "um relato de um sonho adquirir uma significação mais estruturada, próxima ou denunciando um mito privado" (Fleming, 2003, p. 153).

Amaral Dias (1997), num trabalho de reflexão expansiva da tabela dos elementos de Bion, propôs a divisão da categoria $\mathrm{C}$ em duas categorias separadas, sugerindo que o mito figurasse na tabela como categoria D: "Nesta teorização e de uma forma muito sucinta, pensamentos oníricos e sonhos aparecem como a expressão directa da Barreira de Contacto, a qual por sua vez leva à construção dos mitos privados" (Fleming, 2003 , p. 153). Fleming (2003, p. 153) assinala que "os mitos organizam (...) as Conjugações Constantes do sujeito, ou, usando a linguagem dos pacientes, um padrão, ou uma imagem, ou ainda uma ideia recorrente que identificam como estando presente e constante ao longo das suas vidas". O mito privado, sendo constituído e organizado a partir de constelações de fantasias inconscientes do ser humano, oferece-se como um código constituído por um pensamento primitivo e, dessa forma, mais próximo das impressões sensoriais, permitindo produzir saber que, segundo Fleming (2003, p. 153), "é coevo de um pensamento conceptual obedecendo este à lógica do pensamento científico".

A antropologia elucida outras características do pensamento mitológico, que frequentemente é apresentado como detentor de funções normativas e de regulação social. Nas sociedades ditas "primitivas", o ser humano, confrontado com o mundo e com a sua existência no Cosmos, necessitou de o compreender, explicar e de dar significado aos grandes enigmas da sua própria existência (Fleming, 2003). A função 
primeira do mito seria, então, a de desvendar um mistério. De acordo com Mircea Eliade (1957/1989, pp. 10-15), "um mito narra sempre que qualquer coisa se passou realmente, que um acontecimento teve lugar no sentido estrito da palavra". Nesse sentido, traduziria "a revelação de um evento primevo que serviu de base quer a uma estrutura real, quer a um comportamento humano" e "sendo real e sagrado, o mito torna-se exemplar e, por conseguinte, passível de se repetir porque serve de modelo e, conjuntamente, de justificação a todos os actos humanos", concluindo que "o mito é uma história verdadeira que se passou no começo dos tempos e que serve de modelo aos comportamentos humanos".

O pensamento mitológico não se opõe ao pensamento científico mas antes, pela forma como operacionalizam o raciocínio e entendem o mundo, ambos detêm um papel de complementaridade, coexistindo no interior de cada indivíduo (Fleming 2003). Deste ponto de vista, "O mito trágico do Angelus de Millet" poderá conter dois processos de funcionamento mental: 1) o pensamento lógico, analítico; 2) o pensamento intuitivo, criativo (Coimbra de Matos, 2007). Segundo Coimbra de Matos (2007, p. 125), “o pensamento lógico é o pensamento de vigília, do estar vigilante - atento ao real”. A propósito da sistematização, da lógica, racionalidade e coerência, refere o próprio, na terceira pessoa do singular, que "é em 1929 que Salvador Dalí presta atenção aos mecanismos internos dos fenómenos paranóicos e encara a possibilidade dum método experimental baseado no poder súbito das associações sistemáticas próprias da paranóia” (Dalí, 1998, p. 16). Em complemento a este pensamento atento e vigilante, o pensamento intuitivo está associado ao sonho, à distração. Desta forma, "o paradigma do pensamento intuitivo é o sonho acordado, o devaneio ou a rêverie" (Coimbra de Matos, 2007, p. 125), características também presentes no texto em apreço, quando o autor escreve: "o Angelus de Millet adquire uma forma nitidamente obsessiva (...) imiscuindo-se sob diversos aspectos e variantes no desenrolar das minhas fantasias e sonhos" (Dalí, 1998, p. 47).

Muitas poderiam ser, eventualmente, as leituras psicológicas de "O mito trágico do Angelus de Millet”. Porém, a presente análise pretende ser uma contribuição ao estudo deste texto à luz da configuração de um mito privado e da função que este detém para o sujeito. Neste sentido, sugere-se que, diante da ambiguidade da cena reproduzida no Angelus, e ao defender a hipótese de que esta retrata o grande tema mítico da morte do filho, Salvador Dalí esteja a colocar nesta tela uma ideia recorrente da sua existência, mais precisamente a sua condição de criança de substituição. Desse 
modo, as conjeturas que tece sobre a dita pintura, numa linguagem e simbolismo próprios, profundamente influenciada pelos postulados psicanalíticos, e a descrição de um conjunto de sonhos/delírios, poderá fazer sobressair um padrão vivencial, a forma como se sentiu e vivenciou na condição de infante neo-nascido. Neste caso, o texto daliniano poderá ter tido um duplo objetivo para o escritor. O primeiro seria de ordem retrospetiva, na qual a narrativa no tempo passado permitirá um (re) lembrar, um (re)visitar, o paraíso (inferno) de uma infância perdida. Por outro lado, a sua escrita poderá congregar uma função reparadora, na medida que este regresso ao passado poderia permitir a Dalí a (re)construção da sua história pessoal e a finalização da procura de uma identidade própria, atinente a um Eu Ideal grandioso. $\mathrm{Ou}$ seja, seria "O mito trágico do Angelus de Millet" um texto de um tempo passado com o intuito de um ensaio para o futuro?

\section{ALGUNS ASPETOS DA INFÂNCIA E ADOLESCÊNCIA DE SALVADOR DALÍ}

Dalí nasceu a 13 de maio de 1904, na localidade de Figueras, e sete dias depois é batizado com o nome de Salvador Felipe Jacinto Dalí i Domenèch (20 de maio de 1904). Como já foi referido, Dalí vem ao mundo nove meses e onze dias após a morte do seu irmão - Salvador Galo Anselmo Dalí - que morreu com 21 meses de idade, vítima de gastroenterite infeciosa. É, portanto, o segundo filho de Don Salvador Dalí i Cusí, um respeitável notário público e advogado, com forte personalidade e caráter autoritário, associado a um humor sarcástico, que dizem ser próprio daquela região; e de Felipa Domenèch i Ferrés, descendente de uma família com fortes ligações ao mundo comercial e descrita como recatada e moça bonita de Barcelona (Descharnes \& Néret, 1993; Hartman, 2008; McNeese, 2006).

Os primeiros anos de vida de Dalí são marcados por um conjunto de cuidados parentais considerados como excessivos. Com efeito, segundo McNeese (2006), não existiu dia em que estes não satisfizessem os seus desejos, submetendo-se a todas as suas demandas, e o próprio Dalí descrevia-se como tendo sido "uma criança mimada" (Descharnes \& Néret, 1993). Esta condição acabou por ser simbolizada na oferta de uma fatiota de rei por um dos seus tios de Barcelona, que Dalí imediatamente abraça, assumindo-se a partir daí o "monarca absoluto da casa" (Descharnes \& Néret, 1993; McNeese, 2006; Hartman, 2008). 
Segundo McNeese (2006), a superproteção dos pais poderá estar relacionada com a perda do primeiro filho. Todavia, o estado de saúde do segundo filho poderia igualmente justificar cuidados adicionais, visto que frequentemente travava batalhas contra hemorragias nasais e anginas. A sua infância é ainda marcada pelo medo, manifestado através de fobias, especialmente a gafanhotos, assim como por episódios de enurese e encoprese (Descharnes \& Néret, 1993; Hartman, 2008; McNeese, 2006), embora Dalí preferisse acreditar que tinha controlo absoluto destes comportamentos (Hartman, 2008).

Ana María, a irmã, nasce em 1908, ano em que Dalí ingressa na escola. A partir desse momento aumentam em frequência e intensidade os acessos de cólera, seja por não deixar de berrar/chorar até obter o que desejava, seja por manifestar comportamentos agressivos. Dalí alega inclusivamente que teria pontapeado a irmã na cabeça quando esta tinha dois anos, embora este episódio nunca tenha sido confirmado por Ana María (McNeese, 2006; Hartman, 2008).

$\mathrm{Na}$ adolescência, o exibicionismo intensifica-se com o objetivo de atrair cada vez mais a atenção sobre si próprio. Começa por maquilhar-se com produtos de beleza da mãe, deixa crescer o cabelo um pouco abaixo dos ombros para adquirir um "ar de artista boémio", começa a vestir mantas ou capas e a utilizar uma muleta, da qual se tornará inseparável (Descharnes \& Néret, 1993; Hartman, 2008; McNeese, 2006). Nesta fase, acrescem os comportamentos classificados como bizarros e excêntricos no colégio que frequentava. Por exemplo, tira dinheiro aos pais e vende-o por metade do seu valor aos colegas e, aos dezasseis anos, descobre que atrai ainda mais atenção sobre si ao atirar-se pelas escadas do colégio. Poderiam aqui ser traçados pontos de contacto entre este comportamento e o suicídio do avô, que seria um segredo de família apenas revelado a Dalí na adolescência (Hartman, 2008).

É aos dezasseis anos que enfrenta uma das perdas mais significativas da sua vida, com a morte repentina da mãe, vítima de cancro no cólon, que é entendida pelo artista como uma afronta e um insulto, aos quais reage elaborando um plano de retaliação e vingança que passava por alcançar fama e glória nas artes (Descharnes \& Néret, 1993; Hartman, 2008; McNeese, 2006).

Atentemos agora nas representações paternas/maternas de Salvador Dalí. Para o pintor catalão a figura paterna consubstancia-se numa representação tirânica, à qual se poderá associar a prestigiante posição profissional que ocupava e a sua grande e imponente figura, visível na tela "Portrait of my Father" (1925). Contudo, Hartman (2008) assinala que a relação com o pai poderá ser mais complexa do que aparenta à 
primeira vista. Nesse sentido, refere que, embora a maior parte dos materiais biográficos e históricos enfatizem as caracterizações que Dalí fez do pai como homem "castrador" de temperamento volátil, outras assinalam que este seria o homem que mais admiraria e imitaria. É igualmente atribuída ao pai outra das preocupações de Dalí: o sexo. Don Salvador Dalí i Cusí, frequentador assíduo de prostíbulos, culpava-se pela morte do primeiro filho, responsabilizando-se pela transmissão de algum tipo de doença venérea. Por esse motivo, numa atitude de prevenção e educação sexual para com o segundo filho, providenciou-lhe um conjunto de literatura que alertava para os perigos deste tipo de doenças, com ilustrações das lesões provocadas pela sífilis. Mais tarde, Dalí recordar-se-á destas imagens descrevendo-as como repulsivas. Associando-as ao ato sexual, passa a evitar qualquer forma de contacto carnal e refugia-se no onanismo (Descharnes \& Néret, 1993; Hartman, 2008; Martinez-Herrera et al., 2003; McNeese, 2006). Em 1929 dá-se a rutura relacional. O "pai tirano", desaprovando o envolvimento do filho com Elena Ivanovna Diakonova (Gala), deserda o insubordinado. Esta cisão teria sido entendida por Dalí como uma libertação do jugo paterno, rumando até Paris para junto de Gala, para do ponto de vista artístico cimentar o seu talento, aderir ao surrealismo e "renascer" (Descharnes \& Néret, 1993).

Quanto à filiação materna, o discurso é substancialmente distinto, e a mãe parece ser encarada de forma unívoca, desprovida de ambivalência, "religiosamente adorada" (Néret, 2003, p. 14). Em adulto, recorda-a com amor e afeição, descrevendo-a como uma católica devota. Serão de notar aqui as semelhanças com Freud, que também terá idealizado a mãe Amalia (Raphael-Leff, 2010). Na formulação do Complexo de Édipo, profundamente influenciada e determinada pela sua autoanálise, Freud coloca o enfoque na rivalidade com o pai e no desejo pela mãe, relegando para segundo plano a ambivalência pré-natal, a crueldade pós-natal e a cumplicidade na relação incestuosa de Jocasta no mito grego e, por conseguinte, olvidando os aspetos da intimidade diádica precoce com uma mãe arcaica, pré-edipiana (Raphael-Leff, 2010). Tal seria reforçado na sua afirmação de que a relação mãe-filho seria "o mais perfeito, o mais livre de ambivalência de todos os relacionamentos humanos" (Freud, 1933/1996, p. 132). Para Raphael-Leff (2010), Freud teria efetuado uma clivagem defensiva para não entrar em contacto com os aspetos inaceitáveis da mãe, o que conduz a conjeturar se Dalí não teria também realizado o mesmo movimento a propósito do imago materno.

A história de desenvolvimento de Dalí é reveladora de uma vivência pautada, sobretudo, por uma superproteção materna. Segundo McNeese (2006), Dalí terá reve- 
lado que todos os dias a mãe o acordava de manhã, o olhava nos olhos e questionava qual era o seu desejo. Este cuidado materno remete para uma das características apontadas por Hartman (2008) como estando associadas aos progenitores de crianças neo-nascidas, nomeadamente, que estes poderão exibir temor em lidar com a sua própria agressividade, fantasiando que esta possa ferir ou matar o filho vivo. Inaptos em providenciar uma "ressonância negativa" (dizer não) devido ao luto, favorecem, nas crianças de substituição, a perceção de um estado parental de "adormecimento" psíquico. Este embotamento poderá ser percetível nos pais de Dalí que, perante a sua individualidade, cada vez mais problemática, optam frequentemente por desculpá-lo ou mesmo ignorá-lo (Hartman, 2008).

Em linha com o que vem sendo exposto, os comportamentos bizarros, excêntricos e megalómanos que cedo denuncia, e que se intensificam com a adolescência e idade adulta, poderiam associar-se a uma carência de reconhecimento pela sua singularidade, mais precisamente pela mãe, que tanto estimava e valorizava, enlutada pela perda do primeiro filho. Uma desesperada tentativa de diferenciação do irmão morto, também ele Salvador? O próprio o reconhece quando afirma: "todas as excentricidades que Eu cometi, Eu fi-lo porque Eu desejava provar a mim próprio que Eu não sou o meu irmão morto, mas o vivo" (McNeese, 2006, p. 15). Segundo Shanes (1994):

Certamente, aquela morte deixara nos pais de Dalí um inevitável sentimento de angústia, e o jovem Dalí estava sempre consciente do desaparecimento, porque tanto a mãe como o pai projectavam constantemente o irmão nele, fazendo todos os dias comparações entre os dois rapazes, vestindo o Salvador mais novo com as roupas do irmão morto, dando-lhe os mesmos brinquedos para brincar e tratando-o como a reencarnação do outro. Confrontado com uma tal negação de si mesmo, Dalí, compreensivelmente, rebelou-se por forma a afirmar a sua própria identidade, enquanto se revoltava igualmente contra a imagem aperfeiçoada do irmão morto que os pais tentavam impor-lhe. (p. 5)

Nas suas deambulações autobiográficas, Dalí atribuiu grande significado à conexão com o irmão falecido. O seguinte excerto (Dalí, 1942/1986) ilustra como se terá sentido enquanto criança de substituição:

My brother died at the age of seven from an attack of meningitis, three years before I was born. His death plunged my father and mother into the depths of despair; 
they found consolation only upon my arrival into the world. My brother and I resembled each other like two drops of water but we had different reflections. Like myself he had the unmistakable facial morphology of a genius. He gave signs of alarming precocity, but his glance was veiled by the melancholy characterizing insurmountable intelligence. I, on the other hand, was much less intelligent, but I reflected everything. (p. 2)

O discurso, pelos múltiplos erros factuais que contém, ilustra a construção de uma mitologia própria em torno do seu nascimento e a identificação primitiva com o irmão morto (Hartman, 2008). Em 1963 pinta "Portrait of my Dead Brother", que inclui elementos do Angelus de Millet, e alguns anos depois, em escrito autobiográfico (Dalí, 1973/1975), revela as dificuldades na construção de uma identidade própria e a vizinhança da morte associadas à sua condição:

No princípio era a loucura - de que eu fugi. E toda a história da minha arte e da minha vida, até ao encontro com Gala, é a mais terrificante luta contra a morte do espírito. (...) Sabemos que três anos depois da morte do meu irmão, com sete anos, meu pai e minha mãe, com o meu nascimento, atribuíram-me o mesmo nome, Salvador, que era igualmente o de meu pai. Crime subconsciente agravado pelo facto de que no quarto dos meus pais - lugar atraente, receado, cheio de proibições e ambivalências - se encontrava magestosamente a fotografia de Salvador, meu irmão morto, ao lado da reprodução de um Cristo crucificado pintado por Velazquez; e esta imagem do Salvador que, sem qualquer dúvida, Salvador fora encontrar na sua ascensão angélica, condicionava em mim um arquétipo nascido da existência de quatro Salvador que me cadaverizavam. Tanto mais que comecei a assemelhar-me ao meu irmão morto como uma imagem no espelho. Julguei-me morto antes de me saber na vida. Os três Salvador que enviavam a sua imagem, de que um era um Deus crucificado geminado ao outro que estava morto e o terceiro que era um pai imperialista, proibiam-me de projectar a minha vida num molde tranquilizante e direi mesmo que me impediam de me construir. Na idade em que a sensibilidade e a imaginação têm necessidade de verdade essencial e de tutor sólido, eu vivia nos labirintos da morte que se tornou «a minha segunda natureza». Perdera a imagem do meu ser que me tinham roubado, só existia em procuração e prorrogação. (pp. 320-321) 
É significativo salientar que o primeiro capítulo do seu livro autobiográfico "Como me tornei Dalí: As confissões inconfessáveis de Salvador Dalí apresentadas por André Parinaud" (1973/1975), se intitula precisamente "Como conviver com a morte", que esta evocação da omnipresença da morte na sua vida seja associada ao irmão falecido, e que a origem da obsessão fúnebre seja traçada aos alvores da sua existência:

Convivo com a morte desde que sei que respiro e ela mata-me com uma volúpia fria que só tem equivalente na minha lúcida paixão em me sobreviver a cada minuto (...) A minha suprema distracção é a de me imaginar morto, devorado pelos vermes (...) É um exercício útil a que me entrego desde muito, muito novo. (...) Quando criança, o mais pequeno sinal de morte me atormentava o ventre com medo, e a perversidade polimorfa de que bem cedo dei provas flagrantes era sem dúvida um jogo profundo das forças de vida que em mim ocupavam lugar, contra as forças de morte. (...) Nasci duplo, com um irmão a mais, que tive primeiro de matar para ocupar o meu próprio lugar, o meu próprio direito à minha própria morte. (...) Sim, o aniquilamento é fatal. Seremos digeridos pela terra. E nisto incessantemente penso. Nem um dos meus actos, nem uma das minhas criações deixa de se alinhar contra este pano de fundo. Não há um instante da minha vida em que não sinta a presença da morte. (pp. 8-21)

Contudo, a forma como são descritas as reações dos pais perante si e o irmão falecido são substancialmente distintas. É ao pai que são atribuídas e imputadas as principais responsabilidades pelas dificuldades identitárias de Dalí.

Por esse motivo, Dalí (1973/1975, p. 30) dirigia a seu pai os seus "caprichos" e "cóleras": "todos os dias, encontro nova maneira para levar o meu pai ao paroxismo da fúria, ou do medo, ou da humilhação, e obrigá-lo a considerar-me, eu, seu filho, eu, Salvador, como um motivo de desgosto e de vergonha”. A mãe, em contraste, é apresentada sob uma luz idealizada, como personagem cuidadora, que sobre ele vertia o seu amor e o acolhia nos momentos de terror e angústia:

O mundo que me cercava estava cheio de malefícios, cavava-se com buracos de armadilhas. As minhas noites eram povoadas por monstros e eu gritava com pavor. Minha mãe tinha de me embalar nos braços e passava noites e noites comigo ao colo. (...) Minha mãe, no Olimpo daliano, é um anjo. O seu seio, depois o seu sangue, trouxe-me para a vida. A sua voz suave embalou os meus 
sonhos. Era o mel da família. (...) Escuto ainda o som regular da manivela do aparelho de cinema que a minha mãe girava à mão para nos projectar pequenos filmes. (...) Quando penso nela, volto igualmente a ver os cravos que plantava na varanda, ou os minúsculos cactos que utilizava para o presépio de Natal. A morte da minha mãe desesperou-me. Durante muito tempo duvidei do seu desaparecimento. Só ela poderia transformar a minha alma. Senti a sua perda como um desafio e decidido a vingar-me do destino tornando-me imortal. (Dalí, 1973/1975, pp. 27-36)

Contudo, para Etherington-Smith (1992) a mãe teria sido tão "insensível” como o pai às questões que concerniam a substituição operada, assinalando que esta aludia ao primogénito falecido como um "génio" e que levava o jovem Dalí a visitar a campa do seu irmão, sugerindo que a perceção do nome próprio na lápide deveria ser algo bastante perturbador para o segundo filho. Em suma, ambos os pais terão sofrido com a morte do primeiro filho, sofrimento esse que transcorria para o Salvador que viria em sua substituição:

$\mathrm{Eu}$, eu vivi a morte antes de viver a vida. Com sete anos, meu irmão morria de uma meningite, três anos antes do meu nascimento. Minha mãe ficou transtornada no mais íntimo de si mesma. A precocidade deste irmão, o seu génio, a sua graça, a sua beleza, eram para ela outros tantos motivos de exaltação. $\mathrm{O}$ seu desaparecimento foi um choque terrível. Nunca se recompôs desta infelicidade. $\mathrm{O}$ desespero dos meus pais só serenou com o meu nascimento, mas a sua mágoa impregnava todas as células dos seus corpos. E no ventre de minha mãe, já eu sentia a sua angústia. O meu feto banhava-se numa placenta infernal. Esta angústia não me abandonou. Muitas vezes evoquei a existência e a morte deste irmão mais velho, de que encontrei os sinais da sua passagem, desde que a minha atenção despertou - vestuário, retratos, brinquedos - e que deixara na memória de meus pais recordações afectivas indeléveis. Senti profundamente a persistência desta presença ao mesmo tempo como um traumatismo - uma espécie de voo de afeição - e uma exaltação de superação. Todos os meus esforços, dali em diante, tendem para reconquistar os meus direitos à vida e, em primeiro lugar, provocando a atenção, o interesse constante dos meus pais com uma espécie de agressão permanente. (Dalí, 1973/1975, p. 10) 


\section{A EDUCAÇÃO E AS RELAÇÕES DE DALÍ}

A habilidade para as artes, nomeadamente, para o desenho e pintura, brotam precocemente em Salvador Dalí, como uma criança maravilhosa (Amaral Dias \& Amaral Dias, 2015). A primeira pintura realizou-a aos seis anos, mas na escola revelava-se totalmente desinteressado. Os únicos atrativos da escola eram as férias, esperadas com grande expectativa e passadas na casa de campo da família em Cadaqués, onde permanecia longas tardes na companhia de Ana María, brincando junto às formações rochosas e nas poças da água do mar, desvendando a fauna marítima. Também se destaca o convívio com os Pichot, família com fortes amizades no mundo artístico e ligações privilegiadas à sua família (Descharnes \& Néret, 1993; McNeese, 2006). É a Rámon Pichot, irmão do patriarca desta família e também pintor, que é atribuída a responsabilidade de ter apresentado Salvador Dalí a Juan Núñez Fernández (McNeese, 2006). Encarado como o professor que mais o influenciou, a sua tutela de aproximadamente seis anos terá sido responsável pela consolidação dos talentos do jovem pintor. Cada vez mais focado nos estudos artísticos, surgem as primeiras exposições, ao mesmo tempo que alarga os horizontes intelectuais a outras áreas do saber, desenvolvendo os primeiros trabalhos escritos, publicando um poema e reflexões sobre os artistas favoritos, os mestres espanhóis El Greco, Velázquez e Goya e os mestres renascentistas italianos, Miguel Ângelo e Leonardo da Vinci, na revista estudantil "Studium" (Descharnes \& Néret, 1993; McNeese, 2006).

Para alcançar a demanda de fama e prestígio nas artes, motivada pela já referida perda materna, muda-se para Madrid com o consentimento paterno, e ingressa como aluno na Real Academia de Bellas Artes de San Fernando, onde rapidamente se desinteressa pelos estudos académicos e desvaloriza o corpo docente. Simultaneamente, é aceite num grupo de estudantes vanguardistas, privando com Luis Buñuel (que mais tarde integra o movimento surrealista, realizando conjuntamente com Salvador Dalí o filme "Un Chien Andalou” em 1929) e Federico García Lorca, com o qual edifica uma estreita amizade de aproximadamente sete anos, entre 1922 e 1928 (Descharnes \& Néret, 1993; Hartman, 2008; McNeese, 2006).

Nesta fase torna-se anarquista e interessa-se pela política e pela revolução russa, declarando-se favorável à independência da Catalunha. Participa num movimento de protesto contra um professor de arte, exigindo que este abandonasse o cargo por não possuir qualificações para a função. O corolário desta participação é a expulsão temporária da Academia, à qual retorna no outono de 1925, surgindo a primeira exposi- 
ção individual um mês depois, na prestigiada Galeria Dalmau. Finalmente, recusa-se a realizar os exames finais em 1926, alegando faltar aos professores talento suficiente para avaliarem o seu trabalho, o que culminou na expulsão definitiva da Academia (Descharnes \& Néret, 1993; McNeese, 2006). Segundo Hartman (1998), embora seja difícil estabelecer uma conexão direta entre o falecimento da mãe, que ocorre pouco tempo antes da sua ida para Madrid, e os problemas subsequentes enquanto aluno da Academia, existem evidências de que estaria à procura de uma identidade própria e viável, procura essa que se manifestava nas suas vestimentas bizarras, nos conflitos com autoridades políticas e artísticas e no desejo de ser aceite pelos seus pares.

Os 10 anos que se seguiram à morte da mãe, evento descrito por Dalí como golpe tremendo, foram pontuados por intensas dificuldades psicológicas (Hartman, 1998) e por duas das relações mais significativas na sua vida: Federico García Lorca e Gala.

A amizade com Lorca, sete anos mais velho que o pintor, tem início aproximadamente um ano após o falecimento da mãe. A admiração e afeto que nutriam um pelo outro aparentava ser recíproca (Hartman, 2008): "não é de duvidar que os dois rapazes tivessem encontrado um no outro uma paixão das descobertas estéticas, à dimensão dos seus próprios desejos" (Néret, 2003, p. 22). Embora Dalí assevere que recusou algumas investidas amorosas que o poeta entabulou, a dificuldade em separar efabulação de concretude nos seus relatos lança o historiador na ignorância do que efetivamente se passou entre os dois jovens (Néret, 2003). Contudo, e apesar das incertezas que rodeiam esta relação, parece ser possível afirmar que a grande intimidade com o poeta assumidamente homossexual, numa altura em que as suas experiências com mulheres ainda eram bastante limitadas (Néret, 2003), terá agudizado o conflito identitário em Dalí, nomeadamente no que à sexualidade dizia respeito.

Os anos de convívio com Lorca foram um período em que realizou múltiplas experiências ao nível da pintura, com incursões em variados estilos, indiciando a busca de uma identidade artística que, nos últimos anos da década de 1930, parece aproximar-se cada vez mais do surrealismo (Ades, 1982). Em 1928, dá-se o rompimento com Lorca, alegadamente por motivos artísticos. Na primavera de 1929, numa viagem a Paris, visita vários bordéis em busca de uma mulher "elegante". Os seus intentos saem gorados e é um Dalí pessimista e depressivo que regressa a Espanha, estabelecendo um estúdio em Cadaqués. Nesta altura é assaltado por recordações da sua infância, que progressivamente inclui nas suas pinturas, e começa a manifestar "ataques" de riso incontroláveis, que ocorrem em resposta a fantasias intrusivas (Hartman, 2008). 
Segundo Hartman (2008), o rompimento da relação com Lorca coincide com a adoção de uma identidade artística surrealista e com a articulação de um desejo consciente heterossexual. Tanto a perda do companheiro como a ansiedade suscitada pela perspetiva de consumar uma relação heterossexual parecem estar associadas à sintomatologia depressiva e têm um reflexo na sua obra. São desta época os quadros que apresentam os temas freudianos mais evidentes. Embora a maioria dos comentários históricos acerca das produções deste período foquem o conflito entre o desejo heterossexual e a angústia de castração, Hartman (2008) assinala que os "ataques" de riso podem ser lidos como defesas hipomaníacas contra a depressão, associada não apenas à perda de Lorca, mas também da sua mãe e do irmão. A confirmar-se esta hipótese, o fator precipitante para a descompensação psicológica não seria apenas a angústia de castração, mas principalmente o medo da perda do objeto materno.

Por outro lado, a perda da elação da relação de "duplo narcísico", esteticamente idealizada, com Lorca impõe a Salvador a saída do "limbo" pré-edipiano assexuado, em que, muito provavelmente, se rebatia na sua fantasia bissexual regressiva omnipotente, confrontando-o, da sorte, com a angústia de castração (de morte) associada à irrupção do desejo sexual que o colocava perante a incompletude narcísica e a diferença de sexos e de gerações.

É neste estado de grande fragilidade que se produz o encontro entre Dalí e Gala em Cadaqués, seis meses após o rompimento com Lorca. A misteriosa russa cativa de imediato as atenções do catalão, que dela se procura acercar num passeio pelas rochas, mas a declaração de amor é difícil de concretizar entre as gargalhadas nervosas que o assolam:

Eu ia tocar-lhe, ia estreitar a sua cintura, quando a mão de Gala pegou na minha. Era o momento de rir, e ri com um nervosismo tanto mais violento quanto era vexatório para ela, nesse preciso momento. Mas Gala, em vez de se sentir ferida por esse riso, orgulhou-se dele. Com um esforço sobre-humano, aperta ainda com mais força a minha mão, em lugar de deixá-la cair com desdém, como qualquer outra mulher teria feito. A sua intuição mediúnica tinha-lhe feito compreender o sentido exacto do meu riso, tão inexplicável para os outros. O meu riso não era «alegre» como o de toda a gente. Não era cepticismo ou frivolidade, mas fanatismo, cataclismo, abismo e terror. E acabava de fazê-la ouvir o mais aterrador, o mais catastrófico de todos os risos, que lhe depus a seus pés. - Meu querido - disse ela -, não mais nos deixaremos. (Néret, 2003, p. 24) 
Nos seus primórdios, o relacionamento parece ter sido pontuado por fantasias homicidas de Dalí em relação a Gala (acting-out primitivo, dissociativo e confusional, que parece servir de exutório projetivo preferencial à ameaça de castração delirantemente personificada em Gala/objeto de desejo sexual), e esta terá explicitamente pedido ao pintor que consumasse o ato. Salvador Dalí é bastante claro quanto ao papel que Gala desempenhou nesse período da sua vida.

Gala afastou-me do meu crime e curou a minha loucura. Obrigado! Quero amar-te. Casarei contigo... os meus sintomas histéricos desapareceram uns após os outros, como por encanto e tornei-me senhor do meu sorriso, do meu riso e dos meus gestos. Uma nova saúde brotou na minha cabeça, como uma rosa (Néret, 2003, p. 26).

Hartman (2008) refere que embora seja difícil explicar a "cura” operada, é possível especular que Dalí tenha encontrado em Gala um objeto de identificação alternativo aos que até ao momento possuíra. Tratava-se de uma mulher forte, uma curandeira, que passaria a assumir múltiplos papéis na sua vida: editora, agente, amante, companheira, modelo, musa e mãe idealizada (Hartman, 2008). A descrição que faz de Gala, como dotada de carateres masculinos e femininos, aponta para uma figura que congrega os atributos de uma mãe primeva, uma figura omnipotente sem género, contendo em si o brilho de uma plenitude cósmica. Importa recordar que sendo uma mulher imponente de cultura eslava, Gala estaria, provavelmente, impregnada de uma "aura" mística, de raiz ortodoxa, consonante com a fantasmagoria sobrenatural e grandiosa daliniana. A identificação com esta figura parece ter permitido ao artista solidificar, a minima que fosse, a sua identidade sexual instável, enfrentar a separação do pai e da irmã, e superar as perdas de Lorca e da mãe. Para além disso, a russa terá contribuído para a resolução dos seus dilemas sexuais, conferindo-lhe uma identidade heterossexual (Hartman, 2008). Podemos então hipotetizar, a partir do relato analítico de Hartman e das nossas próprias reflexões, que esta frágil identidade masculina, com "incrustações" regressivas de bissexualidade psíquica, inspira a mítica da fusão (do uníssono) das identidades e histórias de vida de ambos. Não será, assim, de estranhar que após o casamento, em 1934, comece a assinar as suas telas como "Dalí-Gala" (Hartman, 2008).

Depois da morte de Gala, em 1982, Dalí deixou de pintar e de criar, e talvez até de viver (Descharnes \& Néret, 1993; Hartman, 2008; McNeese, 2006). Apesar de não 
tentar ativamente o suicídio, relevam-se dois episódios em que se "deixou morrer": o primeiro envolve um "acidente" com um secador elétrico, que causou um incêndio no seu quarto; o outro trata-se de uma desidratação deliberada (Hartman, 2008). Dalí acaba por falecer, a 23 de janeiro de 1989, vítima de falência cardíaca, aos 84 anos, após evidente declínio mental e físico, em profunda depressão (Descharnes \& Néret, 1993; Hartman, 2008; McNeese, 2006). Apesar do otimismo revelado no excerto que a seguir é transcrito, o seu coração não suportou o abalo desta terrível perda.

Não quero encarar a realidade da morte de Gala. O meu espírito teria necessidade de todos os seus recursos para sobreviver. Mas com a preparação que me fez passar estou certo de poder manter a minha inteligência à altura do meu amor pela vida. Sou daqui em diante capaz de suportar a maior das infelicidades, ela porém permaneceria insubstituível. Aliás, tenho pensado muitas vezes na sua morte, desde o primeiro dia do nosso amor e estou preparado para essa tragédia (...) Porque nada é maior que descobrir as suas verdadeiras dimensões e suportar a solidão. Gala ensinou-mo, isto seria ainda uma maneira de lhe prestar homenagem profunda, a continuar a existir como ela quis. (Dalí, 1973/1975, pp. 127-128)

\section{O MITO TRÁGICO DO ANGELUS DE MILLET}

"O mito trágico do Angelus de Millet" é escrito entre 1932 e 1936, nos anos em que viveu em Paris na companhia de Gala (Cirlot, 2003), e permaneceu extraviado por mais de duas décadas. Em 1963, aquando da sua publicação, Dalí (1998, p. 37) escreve no prólogo que "o manuscrito deste livro perdeu-se no momento da nossa partida para Arcachon, horas antes da ocupação alemã. Encontrado hoje, após vinte e dois anos, reli-o e decidi publicá-lo tal e qual, sem mexer uma vírgula”.

O introito da obra esclarece ainda que a sua principal hipótese para a tela, divisada décadas antes, de que representaria o tema mítico da morte do filho, fora validada recentemente por exames de raios X nos laboratórios do Museu do Louvre revelando "uma massa escura de forma geométrica facilmente assemelhável a um paralelepípedo" (Dalí, 1998, p. 39). Esta "massa escura", situada entre as duas personagens, mais não seria do que um caixão contendo os restos mortais do filho dos camponeses enlutados, que Millet teria originalmente pintado, mas apagado com uma camada de 
tinta, pois o melodrama não se coadunaria com os gostos da época. A hipótese avançada é desenvolvida ao longo de três capítulos interligados entre si e exemplificam a aplicação do método paranoico-crítico ao Angelus de Millet.

O primeiro capítulo é dedicado à apresentação do conjunto de "delírios" do autor, que este associa à pintura e que compõem a narrativa do texto, de forma estritamente descritiva e sem qualquer intervenção crítica. Estes fenómenos são classificados por Dalí de acordo com a sua natureza. Assim, o "fenómeno delirante inicial" que produziu um forte impacto sensorial no artista, não só é importante por desencadear os episódios seguintes, denominados de "delírios secundários", mas também por situar a ação no tempo.

Em Junho de 1932 vem-me subitamente ao espírito, sem nenhuma recordação nem qualquer associação consciente que permitissem uma explicação imediata, a imagem do Angelus de Millet. Esta imagem constitui uma representação visual muito nítida e a cores. É quase instantânea e não dá lugar a outras imagens. Sinto um enorme abalo, uma grande perturbação porque, se bem que na minha visão da dita imagem tudo "corresponda" exactamente às reproduções que conheço do quadro, ela "aparece-me" no entanto completamente alterada e carregada de uma tal intensidade latente que o Angelus de Millet se torna de súbito para mim a obra pictórica mais perturbadora, mais enigmática, mais densa, mais rica em pensamentos inconscientes que jamais existiu. (Dalí, 1998, p. 45)

A incapacidade de justificar logicamente esta emoção, através de uma apreciação de ordem intelectual do quadro, permite ao artista deduzir que "a produtividade delirante não é de ordem visual mas muito simplesmente psíquica", ou seja, "não é a imagem que muda de ponto de vista morfológico, porém é do ponto de vista do tema, do ponto de vista do drama" (Dalí, 1998, p. 55) que este deverá ser considerado.

A alteridade dramática é percetível gradualmente, e de forma crescente, quando Dalí desvela o mito trágico contido no Angelus de Millet, através de um discurso associativo construído sob a égide dos "delírios secundários". Primeiro conta um episódio em que está a brincar com seixos e pedras na praia, umas com formas suaves e arredondadas, outras crivadas de buracos pela ação da erosão, colocando-os em poses amorosas. Subitamente coloca duas pedras numa posição evocativa do par de camponeses do Angelus, com o homem representado por uma pedra esburacada com metade do tamanho da pedra "feminina", esta com a superfície polida e inclinada na 
direção da primeira: "o homem aparece assim em estado de ruína, em estado muito nítido de inferioridade face ao seixo arredondado e evocador da figura feminina" (Dalí, 1998, p. 71). Depois relata um choque fortuito, entre si próprio e um pescador de Port Lligat, num prado de ervas grossas e carnudas, que é acompanhado pela súbita lembrança do Angelus. A associação da vegetação que enquadrava este evento com as "noções infantis de flora ante-diluviana", de plantas primitivas e antiquíssimas, suscita a lembrança dos animais e monstros pré-históricos que via em ilustrações de livros que o haviam impressionado na sua infância, e conduzem Dalí a encarar a colisão como um ato falhado, representativo da agressão sexual ancestral. Apesar de esta ser a cadeia associativa seguida por Dalí neste ponto, faz-se aqui um breve parêntesis para salientar um elemento referenciado, mas não destacado pelo autor, que o choque havia sido inevitável pois ambos os homens manifestavam "gestos idênticos e correspondentes como os de um só homem e da sua imagem no espelho" (Dalí, 1998, p. 72), algo que merecerá um comentário suplementar na discussão.

Seguidamente relata uma expedição sua ao Cabo Creus, em que imaginou esculpidas as personagens do Angelus nos rochedos mais altos que compunham a paisagem. $\mathrm{O}$ facto da rocha que representava o homem apresentar-se-lhe como "a que estava mais deformada pela acção mecânica do tempo", da qual "quase nada restava senão o bloco vago e informe da silhueta, a qual se tornava assim particularmente angustiante" (Dalí, 1998, p. 73), condu-lo à corroboração do primeiro "delírio secundário", onde a figura do homem estava igualmente diminuída face à mulher. Contudo, o autor salienta que à noção de diminuição do elemento masculino "vêm agora juntar-se as noções, mais completas, de extinção, apagamento e destruição" (Dalí, 1998, p. 74), adivinhando-se um sentimento de morte.

O discurso prossegue com outro "delírio" secundário, um devaneio fantasioso em que se imagina a sodomizar Gala à saída do Museu de História Natural em Madrid, depois de contemplarem aterrorizados o Angelus na sala dos insetos do museu. $\mathrm{O}$ autor faz uma identificação do par Gala-Dalí com o par de camponeses do Angelus, e o terror sentido aquando da visualização da tela no museu corresponde ao terror da morte, já suspeitado no episódio anterior, sendo este associado ao ato sexual. É igualmente feita referência à sala de insetos, a qual é associada às recordações pessoais dos louva-a-deus. Dalí (1998, p. 77) refere que, por um lado, "o destino do louva-a-deus macho sempre me tinha parecido ilustrar o meu próprio caso face ao amor", por outro lado, a mulher do Angelus parece assumir uma atitude semelhante à do louva-a-deus fêmea (o que sugere a fantasia inconsciente da mãe/mulher primeva 
fálica e "castradora" que incorpora e "enterra" o pénis do filho/homem, ditando a sua emasculação viril e criativa, epítome da colusão de morte e ato sexual "sodomita").

Ao "devaneio" da sodomização de Gala segue-se a "fantasia experimental" de mergulhar metade da tela do Angelus num balde contendo leite morno, surgindo-lhe a dúvida de qual seria a personagem figurada a ser submersa. O labor interpretativo e associativo de Dalí leva-o a concluir que deverá ser o homem, justificando esta conclusão por uma recordação de infância que se reporta às grandes e coloridas ilustrações de um livro infantil: "uma delas, que me causava uma impressão a um tempo agradável e desagradável, representava jovens cangurus na bolsa da mãe; sendo branco o fundo da bolsa, os três canguruzinhos pareciam sobreviver tão bem que eu pensei sempre que estes estavam meio mergulhados em leite" (Dalí, 1998, p. 78). Esta imagem terá motivado o artista à edificação da teoria de que a mãe canguru transportava os filhos numa bolsa contendo leite, assim como a possibilidade de comunicação entre a bolsa e o interior da mãe canguru. Dalí (1998, p. 81) deduz que "a figura masculina do Angelus mergulhada no leite morno apresenta-se-me como uma imagem dum homem submerso, afogado, morto dentro do elemento maternal, dentro do calor materno". Por outro lado, se no "delírio" anterior o par do Angelus era identificado com Gala e Dalí, a presente fantasia conduz o autor a concluir que "Gala ocupava na realidade o lugar da minha mãe" (Dalí, 1998, p. 81), ou seja, o casal de camponeses representariam na verdade mãe e filho. Então, associando este "delírio secundário" aos precedentes, nomeadamente ao sentimento de morte e à ruína/diminuição da personagem masculina, Dalí (1998, p. 81) refere: “a submersão da personagem do Angelus, quer dizer, da minha pessoa no leite maternal, não pode ser interpretada senão como expressão do medo de ser absorvido, aniquilado, comido pela mãe”.

Prossegue a narrativa com um episódio em que descobre, na montra de uma loja, um serviço de café completo, cujas chávenas e cafeteira estavam todas decoradas com a imagem colorida do Angelus. Dalí (1998) refere que a repetição do tema nas chávenas o perturba pelo caráter estereotipado (cada chávena tinha a imagem do Angelus repetida duas vezes, uma de cada lado), o que o induz à alucinose de uma galinha (cafeteira) rodeada pelos seus pintainhos (chávenas) e à interpretação delirante de que o ato de deitar café na chávena simboliza a "união desproporcionada e brutal entre a cafeteira e a chávena, quer dizer da mãe e do filho" (Dalí, 1998, p. 85). O autor refere que, num primeiro momento, dar-se-ia "um crescimento relativo das personalidades, determinado por um apelo a uma nova vida da chávena" (pela introdução do líquido que a começa a encher e modificar, a chávena parece sair a ganhar desta relação com 
a cafeteira); num segundo momento, ocorreria uma despersonalização e aniquilação da chávena (a introdução do líquido acaba por tornar a chávena num simples recipiente da substância que irá ser ingerida, identificando-se com o seu conteúdo). A conclusão desta relação cafeteira/chávena é clara para o pintor catalão: "a mãe devora o filho" (Dalí, 1998, p. 87). Para fortalecer as suas asserções, Dalí (1998, p. 89) associa este evento aos restantes, e termina referindo que "se encontra corroborada a noção do filho submergido e aniquilado pelo elemento maternal".

A sequência dos delírios secundários é finalizada com um episódio em que, durante apenas um segundo, confunde um bilhete-postal colorido do Angelus com um grande cromo representando um monte de cerejas, o que lhe causa um choque violento, acompanhado de angústia. O que aqui é colocado em jogo é o elemento de repetição e estereotipia: "um monte de cerejas não é senão uma grande repetição dum mesmo elemento, elemento que aqui é o par" (Dalí, 1998, p. 90), sendo este elemento associado ao "delírio" anterior: "um serviço de café, sobre cada chávena do qual estão figurados dois pares dos Angelus, associa-se por semelhança, até poder identificar-se, com um monte de cerejas, pressupondo igualmente o monte uma grande reunião de pares" (Dalí, 1998, p. 90). O monte de cerejas reitera o elemento repetitivo do fenómeno precedente e intensifica a estereotipia do filho: "o grande número de Angelus-filhos constituído pela multiplicidade dos dois pares de cada chávena identifica-se (...) com o conjunto dos pares de Angelus-filhos também representados pelas cerejas" (Dalí, 1998, p. 93). A identificação dos pares de Angelus-filhos (chávenas) com as cerejas poderá ser encarado como uma modificação para uma nova cena que visa acentuar e agravar a significação comestível, comummente atribuída às cerejas. Dalí salienta ainda que a associação entre este evento e o precedente afeta apenas as chávenas (o elemento filial). É este elemento filho que é devorado, comido e aniquilado pela mãe.

O terceiro capítulo é dedicado à exposição metódica e resumida do mito trágico contido no Angelus, a qual é realizada em três fases distintas. Na primeira fase argumental constitutiva do mito, Dalí aborda o ambiente geral do quadro, assinalando que a envolvência crepuscular da tela determina sentimentos atávicos. São clarificadas a identidade e posição das duas personagens do mito, incarnados no par do Angelus: 1) a mãe, que adota uma pose expectante similar à da louva-a-deus, antes da relação sexual; 2) o filho, subjugado e privado de vida, "hipnotizado pelo "exibicionismo espectral» da mãe que o aniquila” (Dalí, 1998, p. 100). Na segunda fase do argumento mitológico, “o filho pratica com a mãe o coito por trás, segurando com as 
mãos, à altura dos rins, as pernas da mulher" (Dalí, 1998, p. 100). Esta pose revelaria um elevado grau de animalidade e atavismo e seria simbolizada pelo carrinho figurado no Angelus e também pela forquilha enfiada na terra lavrada. Chega-se então à terceira e última fase do mito, a sua conclusão: "como no amor da louva-a-deus, a fêmea devora o macho depois do acasalamento" (Dalí, 1998, p. 107). Para Dalí, a morte do filho às mãos da mãe, que coloca um final trágico ao mito do Angelus, é sustentado pelos fenómenos das chávenas e das cerejas já descritos anteriormente. O pintor catalão finaliza a prosa descritiva do mito trágico com as seguintes palavras (Dalí, 1998):

Reconheço assim, com extrema evidência, que a personagem masculina me surgia, desde o princípio da primeira cena de expectação, sob um aspecto perturbador, angustiante, via-a "como morta de um modo latente", "como morta antecipadamente". Esta impressão não pode deixar de estar relacionada com a minha identificação com a dita personagem, a qual já foi suficientemente esclarecida. Para acabar, não gostaria de parecer subestimar demasiado a intuição lírica ou puramente sensível do leitor, voltando a referir minuciosamente os factores de "extinção", de "sentimento fúnebre monumental", de "imobilidade" activa da mulher, passiva e aniquilada no homem, e outras circunstâncias e factores de "ambiente argumental", cuja prodigiosa resolução no quadro, por mais onírica que seja, não deixa de contribuir com menor força para fazer ressaltar, da imagem insípida e estereotipada do Angelus de Millet, a variante maternal do mito imenso e atroz de Saturno, de Abraão, do Pai Eterno com Jesus e mesmo de Guilherme Tell, devorando os seus próprios filhos. (p. 107)

Todavia, na descrição da terceira fase do mito, Dalí (1998) acrescenta um trecho algo enigmático, pontuado pela dúvida que, de certa forma, contrasta com a certeza que caracterizava a sua dissertação até este momento:

Há certas determinações, como a do elemento maternal que nos é fornecido pela associação dos sacos, da terra cultivada, do cesto, etc..., que não julgo suficientes, nas quais não quero insistir e que, no fim de contas, até não desejo que sejam tomadas em consideração. Renuncio também, neste momento, a precisar noções que, como a do sentimento de morte, embora as tenha como certas, são de ordem demasiado geral para a presente obra. (p. 107) 
Na conclusão da obra, Dalí dá como estabelecida a utilidade do método paranoico-crítico. As suas ambições haviam sido atingidas, pois tratava-se mais de versar os processos de conhecimento do que os conteúdos. Com efeito, não é tecida qualquer alusão à dimensão pessoal que a história comporta (embora os elementos pessoais estejam parsemeados um pouco por todo o texto), apesar de Salvador afirmar ter realizado um documento de "grande autenticidade".

\section{DISCUSSÃO E CONCLUSÕES}

A partir da década de 1940, Dalí abordou por diversas vezes nos seus escritos autobiográficos (por exemplo, em "The Secret Life of Salvador Dali” ou "Como me tornei Dalí: As confissões inconfessáveis de Salvador Dalí apresentadas por André Parinaud"), e com um grau de profundidade considerável, as terríveis consequências da sua vivência como criança "neo-nascida". Contudo, se aceitarmos como exata a sua datação dos fenómenos delirantes e da redação de "O mito trágico do Angelus de Millet" na década de 1930, este teria sido o primeiro escrito em que abordou o tema da morte do filho, que tanto o perturbou ao longo da sua vida. Segundo Joana e Carlos Amaral Dias (2015, p. 15), esta obra constitui um registo de recordações, ficções e realidades, assente numa descoberta puramente especulativa, parecendo revelar-se como resposta mítica com valor de verdade, desenvolvida para tentar dar conta da sua tragédia particular: "O filho morto do casal de camponeses, que não aparece explicitamente no quadro, parece equivaler à imagem que Dalí fazia do irmão morto, sendo o próprio Dalí aquele que viria a substituí-lo”.

Nesta resposta mítica parecem poder destacar-se três elementos significativos: o momento na história de vida do artista em que ocorrem os "fenómenos delirantes" que sustentam o discurso associativo, pontuado pelo surgimento e permanência em seu redor de Gala, e pelo estabelecimento de uma identidade artística sólida, após flutuações por diversos estilos; as diferenças entre a narrativa mitológica, em que a mãe detém particular destaque, e as narrativas autobiográficas, em que ao pai é outorgada primazia na génese do conflito identitário; as limitações inerentes aos processos de autoanálise e os esforços de Dalí em direção à descoberta da sua verdadeira identidade.

Em primeiro lugar, o período em que emergem os "fenómenos delirantes" descritos no ponto anterior, e a composição do texto (distinta da sua publicação que apenas ocorre décadas mais tarde), é sincrónica com o estabelecimento e sedimentação da 
sua relação com Gala. O impacto desta figura feminina é tão significativo que, para Joana e Carlos Amaral Dias (2015), se revela o elemento diferenciador relativamente a outros vultos das artes, nomeadamente Van Gogh e Antero de Quental, que, inscrevendo-se também eles como crianças neo-nascidas na sua trajetória artística e existencial, não gozaram de proteção idêntica, sucumbindo ao suicídio.

Retomando Bion, nas crianças de substituição a função de rêverie materna parece encontrar-se "sobressaturada pelas recordações, factos e sofrimento ligados à criança morta", sendo que "o sujeito morto faz do sujeito vivo o lugar do duplo narcísico, já que ele é o lugar verdadeiramente investido e amado pela mãe" (Amaral Dias \& Amaral Dias, 2015, p. 19). Esta realidade psíquica parece marcar presença no conteúdo latente da narrativa que compõe o mito trágico, sobretudo no episódio da submersão da tela do Angelus em leite morno, a qual remete Dalí para a recordação de jovens cangurus imersos no leite da mãe canguru, tomados, em sentido kleiniano, como "filhos-pénis" afogados num terrífico úbere materno. Coloca-se então a hipótese destas associações se reportarem à interação precoce entre filho e mãe, caracterizada por "farrapos" proto-oníricos de identificação projetiva negativa, em resultado de um "luto" materno patológico e, como tal, comprometedora de um continente (q) para os conteúdos tóxicos $\left(\sigma^{\top}\right)$ da mente primitiva. Ora, a falência da internalização da função a materna desintoxicante inviabiliza, in fine, uma verdadeira atividade de pensamento diacrítico que a adoção intelectual do método paranoico-crítico, pseudo-elaborativo, parece revelar à exaustão.

Antes de Gala, Salvador Dalí aparenta estar bloqueado numa encruzilhada identitária, em que a única alternativa parecia ser a identificação primitiva com a vítima, mãe e irmão falecidos (Hartman, 2008). O aparecimento desta mulher parece abrir espaço a opções diferentes. Gala opera uma verdadeira renascença na vida do pintor, facultando-lhe um objeto de identificação alternativo.

Este objeto interno primitivo, figura omnipotente em chiaroscuro feminil e fantasmaticamente dotada de uma "aura" de falicidade mística, parece então proporcionar a Dalí a reversão à mítica do Salvador imortal e deífico, como "Filho Unigénito do Pai", no sentido expresso no Evangelho segundo S. João para referenciar Jesus como o único Filho de Deus que com ele compartilha a natureza divina, distinguindo-se na sua singularidade de todos os crentes, filhos e filhas de Deus através da fé.

Por outro lado, a colusão narcísica Dalí-Gala, ao criar um Ser em uníssono, assegura a anulação da angústia mobilizada no seu frágil Ego pela diferença dos sexos, ao engendrar um Ente procriativo hermafrodita, entre o fantasma bissexual e a indi- 
ferenciação sexual, ao mesmo tempo que opera a ilusão da libertação da ordem da Morte ou da "castração simbólica" que, no dizer de Lacan, permite a emergência do sujeito de palavra liberto da fusão especular omnipotente originária com o Outro materno.

Numa perspetiva complementar, os "fenómenos delirantes" descritos por Dalí em "O mito trágico do Angelus de Millet" parecem distinguir-se significativamente dos acting-out das crises histéricas que precedem e pontuam o encontro com Gala, e que aparentam traduzir a evacuação de elementos $\beta$ associados à sua experiência emocional de criança de substituição. Os "delírios" associados ao Angelus apenas surgem posteriormente, no contexto de uma relação estável, e podem ser conceptualizados como pensamentos oníricos, combinados em forma narrativa para descrever o mito privado de Dalí enquanto criança neo-nascida. A reintrojecção da função $\alpha$, inicialmente desempenhada por Gala, ao permitir a (re)construção e (re)visitiação do seu passado, autorizaria a construção de uma nova identidade separada da identidade do irmão morto, porém sempre frágil, porque coludida com a figura de Gala.

Tão importantes como os seus dons de amor, os seus dons de persuasão. O seu discurso é essencial à minha alma. Ela serena-me. Ela revela-me. Ela faz-me. Ela convence-me do meu talento para viver. O método paranóia-crítico deve-lhe tudo. Ela obrigou-me a transformar a minha lucidez numa faculdade de auto-análise que passe pela joeira os meus pensamentos mais terríveis e os mais perturbados, para os transformar em luz e acto. Eu estaria morto sufocado sob a pressão da minha imaginação e dos meus receios. Tornei-me rico com toda a lama que transformei em ouro. Canalizei a torrente das minhas impressões com as quais domestiquei o meu real. (Dalí, 1973/1975, p. 126)

O segundo elemento a analisar relaciona-se com as diferenças entre o relato da relação mãe-filho, constante no mito, e as referências explícitas de Dalí à mãe e à sua condição de criança de substituição nos documentos autobiográficos. Segundo a literatura, ambos os progenitores das crianças de substituição têm um papel relevante na dinâmica familiar, mas o papel da mãe é destacado (Anisfeld \& Richards, 2000; Cain \& Cain, 1964; Hartman, 2008), algo que é consonante com a narrativa mitológica divisada pelo artista catalão, na qual mãe e filho interagem sob o signo da morte. Todavia, nos seus escritos, Dalí parece conferir um papel mais preponderante ao pai, ao qual são atribuídas a maior parte das comparações com o irmão morto e o relembrar de que ele não 
passaria de um substituto para outro que havia morrido (Dalí, 1973/1975; Hartman, 2008). Talvez Secrest (1987) tenha colocado esta questão, aparentemente paradoxal, em termos que conjugam aparência manifesta e interioridade latente:

Dali's mother was the quintessence of all-giving, all-loving maternity. But that seemingly fortunate son, endowed with every possible advantage, his every whim indulged, was by nature hypersensitive to emotional nuance. It is evident that, at an early age, he became aware that he was not being loved for himself. When he looked into his mother's eyes what he saw was not his own reflection, but a ghost. (p. 25)

Neste sentido, a obra "O mito trágico do Angelus de Millet" poderá traduzir um conhecimento acerca de si próprio, que o próprio desconheceria, desvelando as suas conjunções constantes. Segundo Bion, os mitos têm constituído uma fonte de conhecimento para diversas disciplinas, entre as quais se destaca a psicanálise, onde o mito edipiano facultou esclarecimentos acerca do desenvolvimento sexual do ser humano, facilitando igualmente a formulação da teoria psicanalítica. Bion propõe uma estreita associação entre mito e vínculo $\mathrm{K}$, ou seja, com a problemática do conhecimento humano em busca da verdade última em O (Grinberg, Sor, \& Bianchedi, 1972). Ora, o mito daliniano apresenta à partida um elemento que o distingue do Édipo freudiano: a ausência de triangulação. A tónica é colocada, por Dalí, na relação dual entre os camponeses, as duas personagens da cena pictórica: a mãe agressiva, homicida e animalesca; e o filho passivo, submisso, morto e aniquilado. Para além disso, a descrição que é entabulada acerca do coito do filho com a mãe remete não tanto para o desejo edipiano descrito por Freud, mas para fantasias primitivas descritas por Klein (1960), do filho penetrar o corpo da mãe em estádios precoces do Édipo. A tragédia parece, pois, reportar-se às fases mais prematuras do desenvolvimento, à alvorada da sua vida. A escolha da palavra "crepúsculo", para descrever o ambiente do quadro, faculta um suporte adicional a esta hipótese. Com efeito, esta palavra tanto se pode referir à claridade ténue que precede o raiar do dia, evocando o nascimento, como à idêntica claridade que antecede o anoitecer, relembrando a morte, dois elementos intimamente conectados no caso daliniano. A tragédia seria a de um jovem infante que, ao penetrar no corpo da sua adorada mãe, em busca de si próprio, no amanhecer da sua existência, encontra a "morte", as imagens repetidas e estereotipadas de um Outro, idealizado como igual a si próprio (como montes de cerejas aos pares). 
Chega-se, assim, ao terceiro e último elemento. Ao aproximar-se do fecho da sua narrativa, Dalí parece trilhar firmemente o caminho em direção ao autoconhecimento, mas eis que esbarra em dificuldades que podem ser imputadas ao fenómeno egóico da resistência psíquica. No último capítulo, Dalí refere, para perplexidade do leitor, que não deseja aprofundar o elemento maternal nem o sentimento de morte evocados pelo quadro. Por outro lado, o seu discurso assume subitamente uma impessoalidade que contrasta com a intimidade dos capítulos precedentes, e não são tecidos quaisquer pontos de contacto entre as suas vivências pessoais e a interpretação que faz da cena pictórica do Angelus. A impressão veiculada é a de um relato de sonho que é abruptamente desvinculado do seu sonhador. Retomando uma vez mais Bion, a verdade última $(\mathrm{O})$ é, por definição, inatingível, incognoscível. Neste caso, apesar da aproximação, em todos os sentidos notável, à realidade das crianças de substituição, aniquiladas pelas imagens do irmão morto que povoam o interior materno, Dalí não a identifica na totalidade a si próprio. As autobiografias do pintor parecem indiciar uma resistência em perscrutar um outro lado da sua mãe, um lado fálico ou "animalesco", por contraposição ao lado idealizado, benévolo, desprovido de ambivalência, que frequentemente emerge. Neste aspeto, a autoanálise de Dalí aparenta ter alguns pontos de contacto com a de Freud.

Para Dalí, assim como para Freud, parecia ser difícil conceber a mãe como destruidora, como má e mortífera (Anzieu, 1959/1988). Desta perspetiva o pintor aproximou-se sobejamente com a descrição do mito trágico que ele acreditava estar contido no Angelus, de uma mãe "louva-a-deus" a trucidar sem piedade o seu filho. Mas, no último momento, parece recuar perante os ventos dinâmicos que sopravam sobre a sua mente e a colocavam em movimento. Ao longo da sua vida irá escrever muito sobre a experiência de criança de substituição, mas a mãe, essa permanecerá um anjo. Saliente-se ainda, na temática da resistência, o episódio do choque com o camponês, em que, no discurso associativo, Dalí descarta a sua primeira impressão de que parecia um homem a olhar para o espelho, preferindo ver apenas um ato falhado que representaria o ato sexual ancestral. De facto, este episódio parece remeter ao choque identitário com a imagem do irmão morto, que era inevitável no contexto familiar dos Dalí, e que fazia igualmente evocar a imagem do Angelus, mas isso fica por explorar no seu texto. O mito havia sido formulado, desvendado, mas permanecia por decifrar.

Finalmente, este é um texto que, pela sua plasticidade, se presta a múltiplas leituras e a uma interpretação polissémica quando conjugado com os elementos biográficos do pintor. Com efeito, terminado este ensaio, uma outra hipótese se avoluma no 
horizonte para o estudo da mitografia daliniana. Como atrás foi referido, os dados recolhidos parecem indiciar o relevo do mito cristão do Messias ressuscitado, Salvador da Humanidade, na condição de "Filho Unigénito do Pai", como solução romanceada para a problemática central da sua existência enquanto criança de substituição. De acordo com esta alegoria mística, Dalí, in nomine Salvador, incarnaria a divindade para renascer e subtrair-se à Lei da Morte. Esta operação, completada pela união congénita com Gala, confirmaria a inscrição de Dalí num pressuposto de base messiânico (Bion, 1961), em que a diferença de sexos e de gerações é negada, sustentando um fantasma de imortalidade simbólica. Nesta linha conjetural, a pintura adquiriria novos significados, traduzindo a negação da cena primitiva (as duas figuras estáticas,

que não se tocam) através da referência à conceção liberta de pecado (como descrita na prece do Angelus), e o episódio do choque, acima mencionado como representação do ato sexual ancestral, ganharia uma nova dimensão, exigindo uma releitura da obra a realizar, quem sabe, noutros voos indagativos.

\section{REFERÊNCIAS}

Ades, T. (1982). Dalí. London: Thames and Hudson.

Amaral Dias, C. (1997). Tabela para uma nebulosa. Lisboa: Fim de Século.

Amaral Dias, J., \& Amaral Dias, C. (2015). Antero, ou o Nome Próprio. Interações: Sociedade e as Novas Modernidades, 28, 5-21.

Anisfeld, L. \& Richards, A. D. (2000). The replacement child: Variations on a theme in history and psychoanalysis. Psychoanalytic Study of the Child, 55, 301-318. https://doi.org/10.1080/00797308.2000.11822527

Anzieu, D. (1988). A auto-análise de Freud e a descoberta da psicanálise (T. Pérez, Trad.). Lisboa: Edições 70. (Obra original publicada em 1959).

Bion, W.R. (1961). Experiences in Groups and Other Papers. London: Tavistock.

Bion, (1991). Elementos em Psicanálise (P. Correia, Trad.). Rio Janeiro: Imago Editores. (Obra original publicada em 1963).

Cain, A. C. \& Cain, B. S. (1964). On replacing a child. Journal of the American Academy of Child Psychiatry, 3 (3), 443-456. https://doi.org/10.1016/S00027138(09)60158-8 
O Mito Trágico de Salvador Dalí

Cirlot, L. (2003). Dalí y el «Ângelus» de Millet. Pandora: Revue d'études hispaniques, $3,177-184$.

Coimbra de Matos, A. (2007). Vária: Existo porque fui amado. Lisboa: Climepsi.

Dalí, S. (1975). Como me tornei Dalí: As confissões inconfessáveis de Salvador Dalí apresentadas por André Parinaud (F. Sousa, Trad.). Lisboa: Editorial Futura. (Obra original editada em 1973).

Dalí, S. (1978). Le mythe tragique de l'Angélus de Millet: Interprétation "paranoïaque-critique». Paris: Société Nouvelle des Éditions Jean-Jacques Pauvert.

Dalí, S. (1986). The secret life of Salvador Dalí (H. Chevalier, Trad.). Figueres: DASA Ediciones, S.A. (Obra original editada em 1942).

Dalí, S. (2008). Diario de un genio (7ª edição). Barcelona: Fabula Tusquets. (Obra original editada em 1964).

Dalí, S. (1998). O mito trágico do Ângelus de Millet. Lisboa: \& Etc. (Obra original editada em 1963).

Descharnes, R., \& Néret, G. (1993). Dalí. A Obra Pintada. Lisboa: Taschen Editores.

Eliade, M. (1989). Mitos, sonhos e mistérios. Lisboa: Edições 70. (Obra original editada em 1957).

Etherington-Smith, M. (1992). Dalí. London: Sinclair-Stevenson.

Fleming, M. (2003). Dor sem nome. Pensar o sofrimento (2a edição). Lisboa: Edições Afrontamento.

Freud, S. (1996). Novas conferências introdutórias sobre psicanálise. In J. Salomão (Dir.), Edição Standard Brasileira das Obras Completas de Sigmund Freud (Volume XXII). Rio de Janeiro: Imago Editora. (Obra original publicada em 1933).

Freud, S. (2003). Psicopatologia da vida quotidiana (J. Martinho, Trad.). Lisboa: Relógio D’Água Editores. (Obra original publicada em 1901).

Freud, S. (2009). A Interpretação dos Sonhos (M. Resende, Trad.). Lisboa: Relógio D’Água Editores. (Obra original publicada em 1900). 
Grinberg, L., Sor, D., \& Bianchedi, E. T. (1972). Introducción a las ideas de Bion. Buenos Aires: Ediciones NuevaVisión.

Hartman, J. (2008). Dalís Homage to Rothko: a defense against fusion with the victim. The Psychoanalytic Quarterly, 77 (2), 531-567. https://doi.org/10.1002/j.2167-4086.2008.tb00350.x

Klein, M. (1960). The psychoanalysis of children (A. Strachey, Trad.). New York: Grove Press, Inc.

Lacan, J. (1980). De la psychose paranoïaque dans ses rapports avec la personnalité. Paris: Éditions du Seuil. (Obra original editada em 1932).

Lacan, J. (1987). O mito individual do neurótico. Lisboa: Assírio \& Alvim.

Martínez-Herrera, J., Alcántara, A., \& Garcia-Fernández, L. (2003). Dalí (1904-1989): Psychoanalysis and Pictorial Surrealism. The American Journal of Psychiatry, 160, 855-856. https://doi.org/10.1176/appi.ajp.160.5.855

McNeese, T. (2006). Salvador Dalí. New York: Chelsea House.

Néret, G. (2003). Salvador Dalí (L. Filipe, Trad.). Köln: Taschen. (Obra original publicada em 1990).

Rank, O. (1959). The myth of the birth of the hero and other writings. New York: Vintage Books.

Raphael-Leff, J. (2010). Maternal ambivalence and desire - comparing the myths of Oedipus and Ajase. In O. Fukumoto \& K. Matsuki (Eds.), Japanese Contributions to Psychoanalysis, Volume 3. Tokyo: Iwasaki Academic Publisher.

Roudinesco, E., \& Plon, M. (1998). Dicionário de Psicanálise. Rio Janeiro: Zahar.

Rudín, A. (2004). Salvador Dalí desde el psicoanálisis. Arte, Individuo y Sociedad,16, 19-47.

Secrest, M. (1987). Salvador Dalí: A biography. New York: E. P. Dutton.

Shanes, E. (1994). Dalí. Lisboa: Estampa.

Winnicott, D. (1975). O Brincar e a Realidade. Rio de Janeiro: Imago Editora. (Obra original editada em 1971). 